\title{
RACISMO RELIGIOSO, DISCRIMINAÇÃO E PRECONCEITO RELIGIOSO, LIBERDADE RELIGIOSA: CONTROVÉRSIAS SOBRE AS RELAÇÓES ENTRE ESTADO E RELIGIÃO NO BRASIL ATUAL ${ }^{12}$
}

\section{Elina Inkeri Hartikainen ${ }^{3}$}

Resumo: Este artigo estende a análise de Ana Paula Mendes de Miranda quanto à complexa relação entre as ideologias raciais brasileiras e a hostilidade às religióes de matriz africana, bem como à "política dos terreiros" advinda dessa relação, situando-as em um contexto mais amplo de debates sobre o tipo de sociedade que o Brasil é e deveria ser. Para este fim, será examinado como as noções de racismo religioso, de discriminação e preconceito religioso e de liberdade religiosa foram e são articuladas de diferentes maneiras por tribunais brasileiros e por militantes de religióes de matriz africana, e como essas articulaçóes são diferentemente posicionadas e constitutivas das contestaçóes sobre as relaçóes entre Estado e religiấo.

Palavras-chave: religiôes brasileiras de matriz africana, racismo religioso, discriminação e preconceito religioso, liberdade religiosa

${ }^{1}$ Artigo traduzido para a língua portuguesa por Jaime O. D. de Andrade, sob supervisão e revisão de tradução da Profa. Rozane R. Rebechi.

${ }^{2}$ Como citar: HARTIKAINEN, Elina I. Racismo Religioso, Discriminação e Preconceito Religioso, Liberdade Religiosa: Controvérsias sobre as Relaçôes entre Estado e Religião no Brasil Atual. Debates do NER, Porto Alegre, ano 21, n. 40, p. 89-114, 2021.

3 Academy Research Fellow em Antropologia Social e Cultural na Universidade de Helsinki, Finlândia. E-mail: elina.hartikainen@helsinki.fi. ORCID: https:/orcid.org/ 0000-0003-3640-5432. 
RELIGIOUS RACISM, RELIGIOUS PREJUDICE AND DISCRIMINATION, AND RELIGIOUS FREEDOM: CONTESTATIONS OVER STATE-RELIGION RELATIONS IN PRESENT-DAY BRAZIL

\begin{abstract}
This commentary extends Ana Paula Mendes de Miranda's analysis of the entanglement between Brazilian racial ideologies and antagonism towards Afro-Brazilian religions, and the terreiro politics that it has brought forth, by situating them within a broader context of debates about the kind of society Brazil is and should be. To this end, it examines how the notions of religious racism, religious prejudice and discrimination, and religious freedom have been and are variously articulated by Brazilian courts and practitioner activists from Afro-Brazilian religions, and how these articulations are differently positioned in and constitutive of contestations over state-religion relations.
\end{abstract}

Keywords: Afro-Brazilian religions; religious racism; religious prejudice and discrimination; religious freedom.

As religióes de matriz africana têm sido alvo de preconceito e discriminação ao longo de sua história. Já sofreram perseguição da polícia e difamação da imprensa e suportaram o fardo das ansiedades intelectuais quanto à capacidade do Brasil de se construir como nação moderna, tendo sido classificadas criminalmente como curandeirismo, ameaças à saúde pública e charlatanismo (Giumbelli, 2018; Johnson, 2001; Maggie, 1992; Montero, 2009). O status legal dessas religiôes continua precário até hoje. Foram reconhecidas como religióes apenas pela Constituição Cidadã de 1988, mas seus adeptos ainda lutam por ter os seus direitos religiosos reconhecidos. Embora algumas religiôes de matriz africana, particularmente o candomblé e a umbanda, sejam exaltadas como símbolos da herança cultural africana ou inerentemente miscigenada do Brasil desde os anos 1930, os estereótipos negativos sobre elas permanecem fortes em todos os setores da sociedade. É nesse contexto que a guerra contra as religióes de matriz africana, travada desde a década de 80 por certas igrejas evangélicas, incluindo mas não se limitando à Igreja Universal do 
Reino de Deus, encontra terreno fértil ${ }^{4}$. Enquadrada por essas igrejas como uma guerra santa contra o Diabo, nos últimos anos essa campanha assumiu contornos cada vez mais violentos em todo o Brasil. Adeptos de religióes de matriz africana são insultados por vizinhos e por estranhos, impedidos de entrar nas escolas e caluniados publicamente. Também são apedrejados e forçados a renunciar a seus compromissos religiosos e a destruir seus próprios templos sob a mira de uma arma.

Em 2020, esses ataques atingiram um novo nível de sordidez no Rio de Janeiro. Como descreve o artigo recente de Hintz et al. (2021), grupos criminosos assumiram o controle de cinco favelas da cidade e estabeleceram o Complexo de Israel, território governado conjuntamente por traficantes evangélicos e um grupo paramilitar formado por ex-policiais. Essa união sem precedentes entre traficantes, milicianos e evangélicos tem tido efeito particularmente devastador sobre a prática das religióes de matriz africana. Templos têm sido destruídos, líderes expulsos e até mesmo o uso de roupas brancas, comumente associadas às religióes de matriz africana, é proibido.

Que recursos têm os adeptos de religióes de matriz africana para recorrer nessa situação? O que eles podem fazer se nem os agentes do Estado têm controle sobre os territórios em questão? É possível esperar atenção e preocupação por parte das autoridades estatais? $\mathrm{O}$ artigo de Ana Paula Mendes de Miranda, A "politica dos terreiros" contra o racismo religioso e as politicas "cristofascistas" (2021, neste número), responde a essas questôes por meio de atenta análise das formas como os ataques cada vez mais violentos às religióes de matriz africana estão embutidos em um emaranhado mais amplo entre

${ }^{4}$ Pesquisadores vêm se esforçando há algum tempo para saber como descrever os responsáveis por esses ataques às religióes de matriz africana. Embora a Igreja Universal do Reino de Deus tenha atacado as religiôes de matriz africana de maneira particularmente pública, muitos dos ataques fisicamente mais violentos contra os adeptos e templos dessas religióes parecem ser realizados por indivíduos associados a igrejas neopentecostais ou pentecostais menores. Neste comentário, uso o termo "evangélicos" como forma de descrever esses agressores. Essa escolha terminológica, entretanto, não é perfeita, pois dissimula o fato de que muitos evangélicos não participam nem concordam com ataques às religióes de matriz africana. 
a militância evangélica e ideologias raciais profundamente enraizadas no pensamento brasileiro (Miranda, 2021, neste número). Miranda argumenta que essa ligação constitui uma forma particularmente brasileira de "política cristofascista”, termo emprestado de Sölle (1970) e Heyward (1999), que não apenas busca posicionar os valores cristãos no centro da política, mas é racista em sua orientação. Miranda descreve como os adeptos de religióes de matriz africana têm procurado responder a essa situação por meio de uma "política dos terreiros" de ressignificação que chame tanto a atenção do público em geral como do Estado para o cunho racial dos ataques. Contestando o uso generalizado do termo "intolerância religiosa” para descrever os ataques, uma vez que ele sugere que estes poderiam ser remediados por meio da tolerância, os adeptos dessas religióes argumentam que deveriam ser considerados uma forma de racismo religioso ou genocídio religioso contra a população negra do país. Miranda explica que esses novos termos efetivamente reconfiguram a percepçáo dos ataques, tanto por parte da populaçáo quanto por parte das autoridades, como sendo de cunho racial e político, e não religioso e moral, como vinham sendo tratados até então. Com essa abordagem, cobram das autoridades uma resposta política mais firme.

Tanto a recente adoção do termo "racismo religioso" por alguns agentes do Estado quanto os vários programas governamentais introduzidos nos últimos anos para conter a violência contra as religiôes de matriz africana sugerem que esses esforços ativistas foram bem recebidos pelos alvos pretendidos. Entretanto, ao mesmo tempo, conforme descreve Miranda, esses esforços também têm sido confrontados por outras autoridades estatais que sequer consideram as religiôes de matriz africana como religióes e, ainda mais significativamente, por estruturas estatais que, de várias maneiras, ignoram ou minimizam a luta dos adeptos contra a discriminação e os ataques motivados por questóes religiosas. Em seu ensaio, Miranda chama especial atenção à maneira como a implantação do conceito jurídico de liberdade religiosa, em um processo judicial de 2014, privilegiou liberdades de agressores cristãos em detrimento das de suas vítimas, adeptos de religiôes de matriz africana. Sua pesquisa anterior, contudo, detalhou também as maneiras pelas quais o tratamento 
legal dado aos ataques contra essas religióes os minimizam por padrão (ver, por exemplo, Miranda, 2010; Miranda; Côrrea; Almeida, 2019).

Neste artigo, estendo a análise de Miranda sobre a relação entre as ideologias raciais brasileiras e a hostilidade às religiōes de matriz africana, bem como a "política dos terreiros" advinda dessa relaçáo, situando-os na história do direito e da militância que se dirige para a governança estatal de diferenças religiosas e raciais. Particularmente, examino como as noçôes de racismo religioso, de discriminaçáo e preconceito religioso e de liberdade religiosa foram e são articuladas de várias maneiras por militantes de religiôes de matriz africana e por tribunais brasileiros e analiso as implicações dessas articulaçôes para uma abordagem do Estado em relação às religiôes de matriz africana e ao cristianismo evangélico. Nessa perspectiva, procuro compreender como as análises críticas encaminhadas por adeptos das religiôes de matriz africana, de um lado, e pelos operadores da lei de outro, se posicionam em um contexto mais amplo de debates sobre o tipo de sociedade que o Brasil é e deveria ser.

Para desenvolver esta análise, utilizo pesquisas que realizei com militantes de religióes de matriz africana em Salvador desde 2008, bem como pesquisas que desenvolvo atualmente a respeito da constituição legal de ataques a religióes de matriz africana no Rio de Janeiro.

\section{O EsTADO COMO OBJETO E LOCAL DE CONTESTAÇÃo}

O Estado, como observa Miranda, sustenta uma posição ambivalente quanto aos ataques perpetrados contra as religiōes de matriz africana. Se, à primeira vista, parece não compactuar com a violência, na condição de árbitro e garantidor de direitos, percebe-se, com uma observação mais atenta, que ele está vinculado a ela de várias maneiras. O Estado não é apenas o principal perpetrador de violência contra as religiôes de matriz africana em âmbito histórico, mas também continua privilegiando cristãos e liberdades religiosas cristâs acima das religiốes de matriz africana e dos direitos de seus adeptos. $\mathrm{O}$ 
processo legal descrito por Miranda apresenta um exemplo particularmente sugestivo. O juiz inicialmente responsável pelo caso não apenas negou ao candomblé e à umbanda, duas proeminentes religiôes de matriz africana, $\mathrm{o}$ status de religião - julgamento pelo qual se retratou posteriormente -, como também baseou sua decisão em uma concepção de liberdade religiosa que efetivamente privilegiava os direitos dos agressores evangélicos em detrimento dos de suas vítimas, adeptos de religióes de matriz africana.

A associação do Estado com a guerra às religiôes de matriz africana não se limita, contudo, apenas aos atos de perseguiçáo histórica ou ao náo-reconhecimento e marginalizaçáo atual. Paula Montero (2016) argumenta que as próprias condiçóes para o conflito entre evangélicos e adeptos de religióes de matriz africana advêm da revisão, na Constituição de 1988, da relaçáo entre o Estado brasileiro e as religióes. Ao reconhecer a pluralidade religiosa do país, a Constituiçáo concedeu a todos os grupos religiosos maior liberdade para expor suas convicçóes em público, ao mesmo tempo em que acabou os posicionando em competiçôes diretas entre si por recursos e apoio do Estado. Isso propiciou aos evangélicos meios e motivos para declarar publicamente uma guerra contra as religióes de matriz africana. À medida em que cresceu a influência evangélica na política brasileira, a abordagem do Estado em relação ao cristianismo evangélico e às religiôes de matriz africana tornou-se objeto de acalorado debate. No centro desse debate estão questóes como: até que ponto as políticas públicas podem ou devem ser influenciadas por valores ou agendas evangélicas? E quanto ao reconhecimento e proteção das religióes de matriz africana? E, por fim, as diferentes respostas a essas questôes refletem e se sustentam em que tipo de visão de sociedade? (ver Almeida, 2017; Machado, 2020; Mariano, 2011).

Esses debates revelam como campanhas evangélicas contra religióes de matriz africana, e, principalmente, como o Estado age em relação a essas campanhas, tornaram-se pontos de atenção e discussão no Brasil, no que, segundo Hussein Ali Agrama (2012), poderíamos chamar de "espaço-problema” do secularismo brasileiro. O secularismo, argumenta Agrama, não 
constitui somente um sistema político fixo, mas também uma estratégia de questionamento. É impossível estabelecer a linha divisória entre religião e política que o secularismo busca traçar e regular. O próprio esforço de separar religião de política acaba levando ambas ao diálogo, mas não apenas isso; ele também acarreta uma questão definitivamente impossível de responder: como e onde a linha entre religião e política deve ser traçada? Os debates gerados por essa questão são, por padrão, tensos, não apenas devido à dificuldade em distinguir religião e política, mas também pelo que está em jogo. Na verdade, como observa Agrama, os debates nunca são apenas sobre a relação entre religião e política. Eles envolvem, também, disputas sobre diferentes interpretaçóes do papel e do lugar de tais direitos, liberdades e virtudes liberais como igualdade legal, tolerância social e liberdade de crença e de expressão (Agrama, 2012, p. 28).

Esses debates envolvem o Estado de maneira basilar. Se o Estado é levado a refletir e fazer cumprir um modelo de sociedade nacional, em que esse modelo deve consistir é frequentemente objeto de intensa disputa e debate. Em tais debates, diferentes grupos políticos disputam o prêmio de um Estado alinhado com suas visões e interesses. Até certo ponto, política é precisamente isso. O Estado, contudo, não é apenas o tema da discussão, mas também a arena crucial de seu desdobramento. Na verdade, quando acontecem entre ou dentro de diferentes órgãos do Estado é que esses debates tendem a ser acompanhados mais de perto pelo público e têm maior impacto.

O recente desenvolvimento da questão no Brasil é revelador. Assembleias Legislativas tornaram-se locais de debate sobre projetos de lei que ora restringem, ora privilegiam as liberdades referentes à prática de religióes de matriz africana (ver Giumbelli, 2008; Hartikainen, 2019; Scola, 2018). O objeto e o teor das ações do poder executivo quanto à proteção das liberdades religiosas relativas a adeptos de religióes de matriz africana, bem como aos evangélicos, passaram a depender cada vez mais das convicçóes religiosas dos membros do poder executivo e de seus principais apoiadores (Almeida, 2017; Mariano; Oro, 2011; Obalera de Deus, 2019). Além disso, como mostrarei a seguir, os tribunais se tornaram arena para debater tanto os 
limites do direito à liberdade religiosa frente à guerra santa dos evangélicos quanto para o que deveria ser considerado discriminação ou preconceito religioso. Em todos esses debates, estão em jogo, de um lado, o lugar e a interpretaçáo do direito à liberdade religiosa na sociedade brasileira e, de outro, o compromisso do Estado brasileiro com modelos específicos de uma sociedade igualitária e baseada em direitos.

$\mathrm{O}$ aumento de ataques violentos às religióes de matriz africana náo pode ser separado desses debates sobre fundamentos políticos e éticos do Estado e da sociedade brasileira. Se, por um lado, a violência crescente dos ataques reflete uma forma mais atuante e violenta do cristianismo evangélico, como observa Miranda, por outro, ele também está sendo impulsionado pela recente guinada à extrema direita na política brasileira. A associação entre agendas políticas evangélicas e o populismo antidemocrático do governo de Jair Bolsonaro resultou em desmantelamento e reorganizaçáo de agências e programas federais dedicados à proteção dos direitos humanos em geral, bem como dos direitos religiosos dos adeptos de religióes de matriz africana, em especial. A reestruturaçáo do Ministério das Mulheres, da Igualdade Racial e dos Direitos Humanos, renomeado Ministério da Mulher, da Família e dos Direitos Humanos, é um exemplo. Outro exemplo é a nomeação de Sérgio Camargo - negacionista da existência de racismo estrutural no Brasil e responsável por difamar adeptos do candomblé - como chefe da Fundaçáo Cultural Palmares, órgão do governo federal que visa à preservaçáo e apoio à cultura afro-brasileira 5 . Essas mudanças políticas sem dúvida instigaram ainda mais os ataques às religióes de matriz africana. Se, antes do regime atual, uma parcela desses ataques recebeu o devido tratamento legal por conta de sua impropriedade em uma sociedade democrática de direito, o

5 As notícias podem ser acessadas em: https://noticias.uol.com.br/politica/ultimas -noticias/2020/11/20/sergio-camargo-diz-que-racismo-estrutural-nao-tem-sentido-nem-fundamento.htm. Acesso em: 06 dez. 2021 e https://noticias.uol.com.br/politica/ ultimas-noticias/2020/06/04/mae-de-santo-vai-a-policia-apos-ser-xingada-por-sergio-camargo.htm. Acesso em: 06 dez. 2021. 
apoio aberto de Bolsonaro a uma agenda política cristã agressivamente evangélica resultou em efeito oposto: um senso de impunidade e pretexto, entre os responsáveis, para atacar religióes de matriz africana parece ter se intensificado desde sua ascensão ao poder.

A seguir, examinarei como o Estado se posiciona como objeto e espaço para o desdobramento de conflitos entre diferentes entendimentos da sociedade brasileira em relação a esses debates, nos âmbitos ativista e legal, e sobre como o Estado deve responder adequadamente aos ataques às religiôes de matriz africana. Para tanto, concentro minha atenção nas formas ambivalentes em que a relação entre o Estado, as religióes afro-brasileiras e o cristianismo evangélico é configurada por debates sobre o caráter desses ataques e sua relação com concepçóes ativistas e legais de racismo, discriminação e preconceito e liberdade religiosa.

\section{Da Intolerância Religiosa ao Racismo Religioso}

Quando pesquisei sobre militância religiosa de adeptos do candomblé em Salvador, no final da década de 2000, a palavra respeito estava na boca de todos os militantes dessa religião. Em seus eventos e debates, ouvi adeptos argumentarem que lutavam por respeito: respeito por sua religião, respeito por sua diferença religiosa e respeito por seus valores; mas também respeito por parte de instituiçóes e autoridades estatais, respeito do público em geral e, principalmente, respeito de grupos evangélicos, os quais vinham atacando o candomblé e outras religiôes de matriz africana de forma cada vez mais violenta nos anos anteriores (Hartikainen, 2018). Esses apelos por respeito em vez de tolerância invocavam uma máxima associada à Mãe Beata de Iemanjá, anciã defensora do candomblé e militante de longa data no Rio de Janeiro, uma das figuras mais importantes do candomblé na época: "Não quero tolerância! Quero respeito!”. Segundo os militantes de candomblé, essas palavras derivavam das frustraçôes de Mãe Beata com a maneira como os confrontos entre adeptos do candomblé e agressores evangélicos passaram a ser discutidos nas esferas 
pública e política. Por um lado, ela concluiu que o termo intolerância religiosa era suave demais para descrever os níveis de violência física e simbólica que alguns evangélicos regularmente praticavam contra os adeptos do candomblé. Por outro, ela estava frustrada com a forma como a intolerância religiosa implicava que tolerância, em vez de aceitação e reconhecimento respeitoso, seria suficiente para lidar com as diferenças.

Uma década depois, como Miranda explica em seu ensaio, essas frustraçóes passaram a ser encapsuladas em um conjunto diferente de enquadramentos discursivos: primeiramente, o racismo religioso e, mais recentemente, o genocídio religioso contra populaçóes negras. De maneira semelhante aos apelos por respeito que orientaram a política ativista em prol das religiôes de matriz africana no final da década de 2000 , esses enquadramentos chamam atenção à inadequação do termo intolerância religiosa como descritor da marginalizaçấo e da violência que os adeptos de religióes de matriz africana enfrentam constantemente na sociedade brasileira. Entretanto, ao contrário dos apelos por respeito, esses enquadramentos discursivos enfatizam o caráter racista desse tipo de violência. Além disso, eles também servem para redirecionar, da seara moral para a política, a percepçáo pública e das autoridades estatais quanto à discriminação contra as religiôes de matriz africana. O que as mudanças nesses enquadramentos e as maneiras pelas quais eles ressoam $\mathrm{e}$ foram assumidos por diferentes atores podem revelar sobre o espaço-problema mais amplo do secularismo no Brasil? Como eles refletem a constituiçáo de e intervêm nesse espaço-problema?

Quando a noção de racismo religioso foi introduzida por militantes de religiôes de matriz africana na segunda metade da década de 2000, muitos adeptos dessas religióes consideraram chocante a descriçáo da discriminação e da violência religiosa que sofriam como racismo. Semelhante às reticências a esse novo enquadramento, descritas por Miranda, muitos adeptos do candomblé que conheci em Salvador no final da década de 2000 demonstraram preocupaçáo com o foco racial do termo racismo religioso. Sua religiáo, disseram-me, é racialmente universal. Os orixás que cultuavam não se preocupavam com raças, pois raça era questáo humana. 
Os militantes que se esforçaram para apresentar o termo aos adeptos do candomblé em Salvador, na época, estavam bastante cientes quanto a essas preocupaçóes. Muitos deles concordaram com os argumentos em relação à universalidade do candomblé, mas rebateram a hesitação dos colegas adeptos argumentando que o termo buscava chamar a atenção para como os alvos de discriminação religiosa e violência contra as religióes de matriz africana eram determinados pela raça. Embora as próprias religióes não fossem racialmente delimitadas, argumentaram, os ataques aos seus adeptos o eram. Quase sem exceção, os alvos desses ataques eram afro-brasileiros. Esse argumento retumbou nas experiências de agressão religiosa sofridas pelos religiosos do candomblé no fim da década de 2000 em Salvador. Embora o termo ainda não fosse usado pela maioria dos não-militantes que eu conhecia, eles consideraram o argumento racial em sua base convincente.

Desde entáo, o termo racismo religioso passou a ser usado com notável frequência. Não apenas seu quadro de referência se expandiu para abranger uma crítica política mais ampla da noção de intolerância religiosa, como também encontrou um público receptivo muito além das discussões ativistas. Mesmo que a ênfase do termo na raça continue a incomodar alguns adeptos, ele foi, inclusive, adotado por autoridades estatais e legais e acadêmicos que simpatizavam com a situação das religiôes de matriz africana. Talvez o mais relevante disso seja a designaçáo, pelo estado do Rio de Janeiro, do dia 27 de março como o Dia Estadual da Conscientizaçáo contra o Racismo Religioso em abril de $2021^{6}$. O termo também foi assimilado por um notável segmento de promotores, advogados, representantes governamentais nomeados e eleitos, jornalistas e acadêmicos, sendo duplamente útil: a) primeiro como

${ }^{6}$ LYRA, Julio Cesar. Alerj aprova 'Dia Joãozinho da Goméia’, de conscientização contra o racismo religioso; lei aguarda sanção do governador. Extra, Rio de Janeiro, 14 de abr. de 2021: https:/extra.globo.com/noticias/rio/alerj-aprova-dia-joaozinho-da-gomeia-de-conscientizacao-contra-racismo-religioso-lei-aguarda-sancao-do-governador-rv1-1-24969879. html?utm_source=Facebook\&utm_medium=Social\&utm_campaign=compartilhar\&fbclid=IwAR2vUH2ohLyOoB1h_XWshhq7mhZ3nHZADzt1oC3WS0M99ez7DNshyFTcGsQ. Acesso em: 6 dez. 2021. 
substituto para a noção de intolerância religiosa e, b) segundo, como índice do apoio das pessoas que o adotam às análises dos militantes.

A crescente aceitação do termo racismo religioso pelas autoridades estatais demonstra sua especial produtividade discursiva no momento político atual. Como sugere a análise de Miranda, o termo reúne, de forma especialmente eficaz, uma ampla gama de frustraçóes e preocupaçóes políticas. Além de apresentar uma crítica politicamente mais contundente aos ataques às religiôes de matriz africana do que o conceito de intolerância religiosa, o termo racismo religioso remonta aos esforços para conter essa violência de acordo com as preocupaçóes mais gerais sobre racismo na sociedade brasileira. Assim, ele amplia o campo de referência para a questão do racismo e chama a atenção para as complexas e variadas formas em que ele se manifesta no Brasil. O termo propóe que racismo é um problema persistente e generalizado no país. Propóe, além disso, que racismo não se restringe a uma conduta com foco abertamente racial. Ele também pode motivar, tomar forma em e estar intimamente ligado à discriminação e ao preconceito religioso. A esse respeito, a noçáo de racismo religioso intervém diretamente nos debates atuais sobre as formas como raça e racismo organizam a sociedade brasileira. De acordo com essa noção, racismo não se limita a atos declarados de agressão racial, como muitos brasileiros acreditam, mas pauta interaçôes sociais em vários domínios.

Ao mesmo tempo, a noção de racismo religioso posiciona a luta dos adeptos de religióes de matriz africana contra os agressores evangélicos em uma estrutura de discriminação e preconceito racial de formas particularmente efetivas. Como observa Miranda, ao propor que os ataques sofridos por esses religiosos sejam compreendidos como racismo e náo como incompatibilidade de valores e perspectiva religiosa, o conceito reconfigura o conflito entre evangélicos e religióes de matriz africana como político e não moral. Quanto a isso, o conceito também abrange debates mais amplos sobre esforços evangélicos para promover políticas baseadas em valores abertamente antagônicos aos que não partilham de sua visão. Essas políticas, sugere o conceito, não são apenas moralmente questionáveis. Elas são discriminatórias e, portanto, ilegais. 
Adotando, então, o termo racismo religioso, as instituiçốes e representantes do Estado, os operadores da lei, acadêmicos e jornalistas posicionam-se de formas distintas em debates mais amplos sobre o lugar que religião e raça, e, por extensão, valores de igualdade racial e religiosa, deveriam ocupar na sociedade brasileira. Em primeiro lugar, o termo os aproxima daqueles que criticam as desigualdades raciais e religiosas do Brasil. Opondo-se aos que contestam a realidade desses problemas, os usuários do termo consideram que mitigá-los é um dos principais desafios do Estado brasileiro. Ao mesmo tempo, porém, o uso que fazem dele conecta-se a uma postura crítica em relação à crescente influência dos discursos de valor dos cristãos evangélicos na política brasileira. Sugere que tais discursos devem ser entendidos em um registro político, pois não apenas violam os direitos daqueles a quem atacam, mas também prejudicam o projeto político mais abrangente de se alcançar igualdade racial e religiosa para todos os brasileiros.

Em última instância, contudo, como o Estado responde aos ataques contra as religióes de matriz africana? Como esses ataques deveriam ser tipificados? Essas questóes e os debates gerados por elas apontam, no espaço-problema do secularismo brasileiro, uma linha de falha fundamental: o foco no caráter da discriminação e do preconceito religioso, bem como da sua contraparte, a discriminação e o preconceito racial.

\section{Julgando Discriminaçáo e Preconceito}

Se a adoção do termo racismo religioso por um segmento de operadores da lei sugere a aderência do Estado às análises dos militantes de religióes de matriz africana quanto à delineaçáo sistêmica dos ataques contra essas religióes, o modo como esses ataques são julgados revela outra coisa: percebe-se relutância jurídica em reconhecê-los como crimes de discriminação e preconceito religioso, equivalente legal aos crimes de racismo. Em termos jurídicos, incitamento e prática de discriminação e preconceito religioso são crimes inafiançáveis desde 1997, quando a Lei n. 7.716/89 - conhecida popularmente como Lei Caó, em homenagem a seu autor, Carlos Alberto 
Caó Oliveira dos Santos - recebeu uma emenda para abranger ofensas contra a religiáo ${ }^{7}$. A lei alterada, que originalmente tratava apenas do preconceito e da discriminaçáo por raça e cor, foi recebida com entusiasmo por adeptos de religiôes de matriz africana. Entretanto, tal entusiasmo logo deu lugar à decepção. A lei não foi aplicada. Nem a polícia, que atribuiu as tipificaçôes iniciais aos ataques denunciados, nem os juízes responsáveis pelos casos resultantes dessas denúncias pareceram reconhecer a validade do quadro legal (Miranda, 2010). Em vez disso, os ataques continuaram a ser tratados como crimes menores, isso quando eram reconhecidos como crimes passíveis de julgamento (Miranda; Côrrea; Almeida, 2019). É notável que continua diminuto o número de casos julgados que resultam em condenaçôes por discriminação e preconceito religioso.

Até certo ponto, essa relutância jurídica em reconhecer os ataques às religiôes de matriz africana como crimes de discriminação e preconceito religioso reflete as percepçôes daqueles que recebem, administram e julgam as queixas dos adeptos. A pesquisa de Miranda sobre os desafios envolvendo denúncias é reveladora. Conforme ela descreve em um artigo de 2010, os policiais do Rio de Janeiro no fim do ano 2000 consideravam ataques religiosos contra religióes de matriz africana "feijoada", termo usado pela polícia para crimes cujo registro e investigação têm menor importância (Miranda, 2010, p. 135). Essa visão se correlacionava diretamente à tipificação de tais ataques como infraçóes menores. Os efeitos dessa prática policial foram, então, agravados pelas trajetórias jurídicas que criaram. A tipificação inicial desses casos como crimes de injúria pela polícia os levou a julgamento no sistema judiciário conciliatório e não ao criminal (ver também Miranda; Côrrea; Almeida, 2019). Nesse contexto, eles eram, por padrão, tratados como produtos de conflitos interpessoais menores. Em

7 A Lei n. 8.081/90 alterou a Lei n. 7.716/89 para incluir religião entre os atributos de identidade cuja discriminação foi criminalizada, se realizada por meios de comunicação. Em 1997, ela foi alterada pela Lei n. 9.459/97 para abranger todas as formas de preconceito ou discriminação contra religiấo. 
vez de serem caracterizados como agressão à liberdade religiosa, as ofensas foram caracterizadas e, como tal, interpretadas pelos juízes como disputas entre vizinhos e brigas menores ("picuinha de vizinho", "abobrinha”), sendo solucionadas mais adequadamente no contexto da família ou da vizinhança do que no tribunal (Miranda, 2010, p. 140). Promotores do Ministério Público envolvidos nos casos também os interpretavam como infrações menores, que refletiam a "falta de educação" dos infratores ao invés de preconceito religioso, ou então enxergavam os esforços das vítimas mais como um meio de alertarem para as ofensas que acreditavam ter sofrido do que uma tentativa séria de reparação judicial (Miranda, 2010, p. 141).

Náo reconhecer os ataques às religióes de matriz africana como crime de discriminação e preconceito religioso também faz parte, no entanto, da forma como a Lei Caó passou a ser interpretada pelos tribunais brasileiros. A saber, a lei foi entendida como aplicável apenas a atos dirigidos a grupos em geral. Como resultado, ofensas à religião, raça, cor, etnia ou nacionalidade de um indivíduo ou de um pequeno grupo de indivíduos não são consideradas crime de preconceito e discriminação. Em vez disso, caem sob a égide de quadros legais preocupados com crimes menores, como a injúria. Para os crimes de discriminação e preconceito religioso, o Supremo Tribunal de Justiça estabeleceu jurisprudência numa decisão de 2012. Em sua decisão, o STJ argumentou que a tipificação de crimes de discriminação ou preconceito religioso nos termos da Lei n. 7.716 deveria ser reservada àqueles cuja vítima fosse um grupo náo especificado de adeptos individuais ou todos os adeptos de determinada religiáo. Se o objetivo fosse atacar a honra de um indivíduo por meio de referência a suas crenças religiosas, o crime seria tipificado como injúria qualificada.

Os tribunais também impuseram outras condiçôes que limitam drasticamente a aplicação da Lei Caó contra crimes de preconceito e discriminação. Exemplo disso é um julgamento envolvendo alegaçóes de discriminação e preconceito religioso, ocorrido na cidade de Salvador em 2009. Naquele ano, um templo de candomblé foi demolido pela SUCOM, Superintendência de Controle de Uso do Solo do Município. A prefeitura alegou estar resolvendo 
uma denúncia feita por uma associação de moradores preocupados com uma estrutura construída em via pública. $\mathrm{O}$ caso foi levado à Justiça pelo Ministério Público, que acusou a prefeitura, a associação de moradores e a equipe de demolição por discriminação e preconceito religioso. Entretanto, como todos os acusados negaram que suas açóes foram motivadas por preconceito religioso, o juiz responsável encerrou o caso por falta de provas de dolo (Hartikainen, 2019).

A pesquisa dos estudiosos da área do Direito quanto ao tratamento das denúncias de discriminação e preconceito racial mostra que os obstáculos enfrentados por adeptos das religióes de matriz africana ao tentarem fazer com que ataques contra sua pessoa e seus templos sejam legalmente reconhecidos como crimes não se limitam ao campo religioso. Estão, na verdade, intrinsecamente ligados à forma como os tribunais interpretam a Lei Caó de maneira geral. Tanya Hernández (2013) demonstra que o foco na intenção é característica comum do tratamento legal dado à discriminação racial tanto no Brasil quanto no resto da América Latina; enquanto Machado et al. (2016) demonstram que os tribunais frequentemente minimizam denúncias envolvendo ofensas raciais. Hernández (2013) e Machado et al. (2016) explicam essa tendência de ignorar e minimizar ofensas raciais como produto conjunto dos limites do direito penal e da influência de um consenso da sociedade que enxerga os crimes raciais como socialmente aberrantes. Hernández e Machado et al. argumentam que a forma como o direito penal enxerga o crime - como algo praticado por indivíduos - impede os tribunais, a princípio, de considerar os contornos sociais mais amplos dos delitos em análise. Isso, com efeito, torna o quadro jurídico incapaz de considerar o preconceito e a discriminação como problemas sistêmicos. Ao mesmo tempo, o tratamento legal desses casos também é influenciado por noçóes equivocadas e profundamente enraizadas na sociedade sobre o caráter do racismo. Como observa Hernández, os tribunais tendem a julgar o racismo como um fenômeno praticado por indivíduos isolados motivados por preconceitos anormais, e não como um fenômeno acobertado por todos os membros da sociedade (Hernández, 2013, p. 99). A autora argumenta 
que essa visão reflete a forma como a conduta racista continua sendo vista como isolada ou decorrente de defeito de caráter e não como problema sistêmico de toda a sociedade, apesar do amplo reconhecimento da organização racialmente desigual das sociedades na América Latina. Semelhante análise poderia ser estendida à percepção dos crimes contra religióes de matriz africana no Brasil.

Essa estrutura legal, a opinião desdenhosa dos operadores da lei sobre a gravidade dos ataques realizados contra as religióes de matriz africana e a influência de práticas e interpretaçóes jurídicas estabelecidas nos casos envolvendo discriminação e preconceito racial, em conjunto, representam um tremendo obstáculo para a aplicação da Lei Caó aos crimes cometidos contra as religióes de matriz africana. Não surpreende que adeptos dessas religiôes encontrem dificuldades para fazer valer seus esforços em prol da aplicação da lei aos ataques contra suas religiôes. Apesar disso, eles lutam por sua aplicação desde meados de 2000. Em seu artigo, Miranda sugere que, considerando a futilidade desses esforços, eles podem ser mais bem compreendidos como tendo o objetivo de levantar uma discussão pública sobre como ataques às religióes de matriz africana continuam sendo menosprezados pelo Estado como ofensas menores em vez da aplicação da Lei Caó. $\mathrm{Na}$ verdade, o que está em jogo nesses casos nunca se limita a questóes de aplicação ou definição legal, mas sempre diz respeito às maneiras como os ataques às religióes de matriz africana estão posicionados no tecido social e moral da sociedade brasileira em geral.

A desconexão entre as formas como os tribunais tratam os ataques às religiôes de matriz africana e os apelos de adeptos militantes para que sejam reconhecidos como preconceito religioso não reflete, portanto, apenas diferentes entendimentos quanto aos objetivos e escopo da Lei Caó, mas também uma linha de falha mais profunda nas concepçóes do lugar de tais crimes na sociedade brasileira e como o Estado deve ou não abordá-los. Para os militantes, tanto as infraçóes de cunho ofensivo quanto a incapacidade da Justiça em combatê-las refletem arraigados preconceitos e estruturas de discriminação que não têm lugar em uma sociedade democrática de direito, 
religiosa e racialmente igualitária. Em contraste, a resposta legal tende a posicionar todas essas infraçôes - com exceção das indubitavelmente intencionais - contra grupos religiosos num patamar abstrato, como expressóes comuns à conduta diária moralmente anormal de indivíduos "incultos", que seriam mais bem resolvidos no contexto da família ou da comunidade do que com mediação das autoridades.

Mas para onde aponta essa linha de falha? A análise acima parece sugerir que ela separa o Estado e, em particular, sua estrutura jurídica e suas operadoras, dos adeptos de religióes de matriz africana e seus apoiadores. Isso pode ser verdade na maioria dos casos de crimes contra essas religiōes. Entretanto, os debates jurídicos que os poucos casos julgados com resultado favorável às religióes de matriz africana levantaram sobre o caráter e os contornos do direito à liberdade religiosa demonstram que essa linha de falha também divide o estabelecimento jurídico.

\section{Debatendo o Escopo e os Limites da Liberdade Religiosa}

O processo discutido por Miranda em seu artigo coloca em primeiro plano outra linha de falha nas discussóes sobre ataques às religióes de matriz africana no Brasil: a do caráter legal e do status da liberdade religiosa. De acordo com a autora, embora a atençáo pública ao caso se concentrasse na alegaçáo do juiz responsável de que o candomblé e a umbanda não eram religiōes, a decisão teve base em uma definiçáo de liberdade religiosa que privilegiava o direito de os evangélicos expressarem livremente suas convicçôes independentemente dos danos que poderiam causar a outras pessoas. Embora os vídeos do YouTube que o caso tratava fossem de péssimo gosto, argumentou o juiz, eles estavam protegidos pelo direito à liberdade de expressão. Por essa razão, os vídeos seriam permitidos ${ }^{8}$. Ao discutir o caso, Miranda entende que a decisão não apenas privilegiou os direitos religiosos dos agressores evangélicos responsáveis

8 PINTO, Marcelo. Juiz recua em manifestaçóes sobre religiōes africanas, mas mantém decisão. Consultor Jurídico, Rio Janeiro, 21 de maio de 2014. Disponível em: https://

Debates do NER, Porto Alegre, ano 2I, N. 40, P. 89-i I 4, AGo./Dez. 202 I 
pelo vídeo e por sua divulgação, mas também reproduziu um entendimento particularmente evangélico da liberdade religiosa como um direito que náo pode ser restringido por estranhos (Miranda, 2021).

A análise do juiz sobre o escopo da liberdade religiosa não representou, contudo, um consenso jurídico, pois, como o desenvolvimento do caso revela, a relação da liberdade religiosa com outros direitos é um assunto altamente debatido no âmbito da lei. Conforme observa Miranda, a decisão do juiz foi revogada pelo Tribunal Regional Federal da 2a Regiáo (TRF2). Contrariando a decisão inicial sobre o assunto, o tribunal de apelação argumentou que o princípio da liberdade religiosa não se estendia à disseminação de conteúdo religiosamente ofensivo. Ou seja, a liberdade religiosa não era um direito absoluto, mas sim limitado por outros direitos, como o direito à dignidade da pessoa humana. Assim, a divulgaçấo de material com potencial de ofender ou incitar ódio, discriminação e intolerância contra uma religião não estava amparada por lei'.

$\mathrm{O}$ caso mencionado não foi um incidente isolado. Semelhante disputa entre análises legais quanto ao caráter e aos limites do direito à liberdade religiosa caracterizou outro caso emblemático envolvendo disseminação de conteúdo religiosamente ofensivo na internet. $\mathrm{O}$ processo, o primeiro no Brasil a resultar em condenação por discriminação e preconceito religioso, foi debatido em todas as instâncias do sistema jurídico brasileiro até ser dado por encerrado em 2018 pelo Supremo Tribunal Federal. Esse processo envolveu duas pessoas: Tupirani da Hora Lores, pastor da Igreja Pentecostal Geração Jesus Cristo, e Afonso Henrique Alves Lobato, membro da igreja condenado anteriormente por ter destruído um centro de umbanda no Rio de Janeiro. $\mathrm{O}$ pastor postou em seu blog insultos a diversos grupos religiosos diferentes do seu; Lobato publicou um vídeo no YouTube comemorando a destruiçáa

www.conjur.com.br/2014-mai-21/juiz-recua-manifestacoes-religioes-africanas-mantem-decisao. Acesso em: 6 dez. 2021; ver também Hartikainen, 2019.

9 Ação Civil Pública, processo n. 2014.00.00.101043-0, Tribunal Regional Federal da 2a Região. 
de um templo de umbanda. Ambos foram considerados culpados pelo crime de incitação e prática de discriminação e preconceito religioso pela 20a Vara Criminal do Rio de Janeiro, e condenados à pena de prisão e multa. Ambos apelaram da decisão ao Tribunal de Justiça do Estado do Rio de Janeiro, mas tiveram seu recurso rejeitado. Posteriormente, o advogado de Lores apresentou pedido de Habeas Corpus ao Superior Tribunal de Justiça, alegando que o pastor havia sido preso ilegalmente, pois suas açóes estariam protegidas pelo princípio da liberdade religiosa. Quando o STJ indeferiu o pedido em 2017, o caso foi encaminhado ao Supremo Tribunal Federal, que também o rejeitou em 2018, mas, ao contrário das instâncias anteriores, não foi unânime em sua decisão. Os Ministros do STF dividiram-se sobre a questão da liberdade religiosa. Enquanto a maioria concordou com a análise do STJ, de que a conduta de Lores havia ultrapassado os limites, o Ministro Fachin divergiu, argumentando que as açôes de Lores não poderiam ser consideradas crime. Embora essas açôes fossem "absolutamente repreensíveis e arrogantes", elas advinham de um compromisso religioso para com o proselitismo e, portanto, deveriam ser protegidas pelo direito à liberdade religiosa ${ }^{10}$.

Conforme demonstra Winnifred Sullivan (2005), a noção de liberdade religiosa convida a debates sobre a sua interpretação. A lacuna revelada por esses debates sobre a liberdade religiosa é inerente à noção legal, que não define a religiáo - objeto que busca proteger -, mas, pelo contrário, exige que os juízes opinem sobre quais religiōes e práticas religiosas devem ser protegidas pelo Estado e em que medida. Os desafios impostos por essa exigência são claramente ilustrados pelos debates judiciais sobre a derrogaçấo evangélica às religiôes de matriz africana. Deveria a lei proteger esse tipo de ofensa motivada por religiáo, qualificando isso como parte da religiáo a receber proteção legal? No caso de não se qualificar, como sua condição não amparada por lei deveria ser considerada legalmente?

${ }^{10}$ Disponível em: http://portal.stf.jus.br/noticias/verNoticiaDetalhe.asp?idConteudo=371511, https:/politica.estadao.com.br/blogs/fausto-macedo/supremo-mantem-acao-contra-pastor-tupirani-por-incitacao-a-discriminacao-religiosa/. Acesso em: 6 dez. 2021. 
Ironicamente, o que tende a ser deixado de fora desses debates jurídicos no contexto brasileiro é a liberdade dos adeptos de religióes de matriz africana de as praticarem sem sofrerem ofensas ou violência, uma vez que as análises jurídicas apresentadas pelas autoridades justapóem o direito dos agressores evangélicos à liberdade religiosa com noçôes mais amplas como dignidade humana e valores nacionais. As justificativas fornecidas pelo TRF-2 e pelo STF para seus argumentos quanto aos limites da liberdade religiosa nos casos acima discutidos são contundentes. Enquanto o TRF-2 fundamentou sua análise em um argumento sobre a necessidade de equilibrar liberdade religiosa e dignidade humana, os Ministros do STF contestaram a reivindicação de Lores à proteção do direito à liberdade religiosa por meio de argumentos sobre os valores brasileiros. Assim, o Ministro Toffoli argumentou que as postagens do blog de Lores entravam em conflito com a história do Brasil como país de tolerância religiosa. O Ministro Lewandowski declarou que as postagens ofendiam a ideia constitucionalmente estabelecida da sociedade brasileira como fraterna, pluralista e sem preconceitos. O Ministro Gilmar Mendes, ainda, enfatizou a convivência harmoniosa, no Brasil, entre os mais diversos grupos que, em outros lugares, se encontravam em estado de guerra ${ }^{11}$.

Pode-se argumentar que essa falta de atenção à liberdade religiosa das religiôes de matriz africana é produto da estrutura jurídica por meio da qual os casos são julgados. A Lei Caó foca o agressor e o caráter de suas ofensas, e não a experiência das vítimas, o que é claramente demonstrado pela ênfase em intenção e foco nos julgamentos desses casos. Isso também revela, contudo, uma lacuna maior no tratamento legal dos ataques contra religiôes de matriz africana. Em nenhuma das estruturas legais disponíveis aos adeptos dessas religióes, a liberdade religiosa fornece argumento capaz de contestar os ataques.

${ }^{11}$ Disponível em: http://portal.stf.jus.br/noticias/verNoticiaDetalhe.asp?idConteudo=371511, https://politica.estadao.com.br/blogs/fausto-macedo/supremo-mantem-acao-contra-pastor-tupirani-por-incitacao-a-discriminacao-religiosa/. Acesso em: 6 dez. 2021. 


\section{Conclusáo}

Em sua análise do "espaço-problema” do secularismo, Agrama (2012) foca o conceito jurídico de ordem pública. Ele argumenta que, em muitos contextos jurídicos liberais, o poder questionador do secularismo repousa sobre esse conceito. A ordem pública está no cerne do Estado de Direito, mas também fornece um meio para expressar e consolidar certos imaginários da nação. $\mathrm{Na}$ análise de Agrama, isso fica particularmente nítido no tratamento legal da religião. Como o autor demonstra com o caso do Egito, a ordem pública fornece uma justificativa para a regulamentação de religióes minoritárias.

Historicamente, o conceito de ordem pública também é central para a regulamentação das religiōes minoritárias no Brasil. Até 1988, a prática de outras religióes que não o catolicismo era limitada ao âmbito privado e a locais de culto, e também a práticas conformes às convençôes de "ordem pública" e "bons costumes". A Constituição de 1988, no entanto, removeu esse tipo de restrição à prática religiosa. $\mathrm{Na}$ ausência dessas restrições, o foco do debate nos âmbitos jurídico e político voltou-se a outros princípios, com especial destaque ao da liberdade religiosa, mas, como sugiro neste artigo, também ao de discriminação e preconceito religioso e racial. Como propus acima, as contestaçóes sobre o caráter e os contornos desses princípios refletem e procuram responder às profundas preocupaçóes quanto à mudança das relações entre Estado e religião no Brasil. Ao mesmo tempo, porém, esses conceitos e as formas como foram definidos pelo sistema jurídico permanecem vinculados a imaginários raciais e religiosos específicos de nação.

Isso é perceptível na resposta legal dada à discriminação e ao preconceito racial e religioso. Conforme detalhado acima, o potencial transformador desses instrumentos legais é gravemente restringido tanto por seu foco em agressores individuais e nas intenções desses agressores quanto por sua limitação ao tratar de ofensas cometidas contra grupos raciais ou religiosos definidos de forma não-individualizada. Esses instrumentos não apenas reforçam o caráter desses crimes como incidentes isolados, mas também reproduzem e intensificam o 
entendimento predominante de que tanto os preconceitos quanto os crimes que eles motivam são algo isolado, moralmente excepcional e, essencialmente, fora do que poderia ser considerado "brasileiro". Como resultado, eles contribuem para o contínuo desconhecimento e apagamento dos antagonismos e desigualdades religiosas e raciais que pautam as interaçóes sociais e a própria sociedade no Brasil.

Analisando-se mais detalhadamente, isso também é verdade para os debates jurídicos quanto ao escopo da liberdade religiosa. De fato, mesmo quando simpatizam com a situação das religiôes de matriz africana, os juízes tendem a basear suas decisóes em argumentos que ignoram a liberdade religiosa dos adeptos de religióes de matriz africana. Suas análises, pelo contrário, baseiam-se em esforços para determinar os limites da liberdade religiosa dos evangélicos em relação às noçôes de dignidade humana ou de valores nacionais de tolerância, fraternidade e harmonia religiosa.

A recente adoçáo do conceito de racismo religioso por alguns operadores da lei e agentes do Estado parece perturbar esses imaginários, ao menos parcialmente. Conforme sugeri acima, a noção de racismo religioso não apenas chama atenção para os contornos políticos dos ataques às religiôes de matriz africana, mas também traz análises críticas quanto à organização racial da sociedade brasileira em diálogo com as preocupaçóes sobre a influência cada vez maior dos valores evangélicos na política e na sociedade brasileira. Nisso, o termo racismo religioso fornece um contraponto particularmente interessante à política "cristofascista" racialmente motivada contra as religiôes de matriz africana e promovida pelos agressores evangélicos descritos por Miranda.

Neste momento, podemos apenas especular sobre como esses acontecimentos mais recentes irão impactar a resposta legal contra os ataques às religióes de matriz africana. É certo, contudo, que as respostas a esses ataques terão efeito decisivo nas experiências dos adeptos nos próximos anos. $\mathrm{Na}$ verdade, conforme a violência do cristofascismo continua, a resposta do Estado aos abusos advindos desse problema dependerá de como os conceitos legais de liberdade religiosa e de discriminação e preconceito religioso sejam 
interpretados e postos em prática. Aqui, a atenção a como as interpretaçóes jurídicas desses conceitos situam-se em debates sociais mais abrangentes sobre religião e raça certamente aumentará nossa compreensão de como e por que os tribunais respondem aos ataques às religióes de matriz africana da maneira como o fazem.

\section{REFERÊNCIAS}

AGRAMA, Hussein Ali. Questioning Secularism: Islam, Sovereignty, and the Rule of Law in Modern Egypt. Chicago: University of Chicago Press, 2012. ALMEIDA, Ronaldo de. A onda quebrada - evangélicos e conservadorismo. Cadernos Pagu, n. 50, 2017.

GIUMBELLI, Emerson. A presença do religioso no espaço público: modalidades no Brasil. Religiáo \& Sociedade, v. 28, p. 80-101, 2008.

GIUMBELLI, Emerson. When religion is culture: observations about state policies aimed at Afro-Brazilian religions and other Afro-heritage 1. Sociol. Anthropol., v. 8, n. 2, p. 401-426, 2018.

HARTIKAINEN, Elina I. A politics of respect: Reconfiguring democracy in Afro-Brazilian religious activism in Salvador, Brazil. American Ethnologist, v. 45, n. 1, p. 87-99, 2018.

HARTIKAINEN, Elina I. Adjudicating Religious Intolerance: Afro-Brazilian Religions, Public Space, and the National Collective in Twenty-First-Century Brazil. Religion and Society, v. 10, n. 1, p. 92-110, 2019.

HERNÁNDEZ, Tanya K. Racial subordination in Latin America: the role of the state, customary law, and the new civil rights response. New York: Cambridge University Press, 2013.

HEYWARD, Carter. Saving Jesus from those who are right: rethinking what it means to be Christian. Minneapolis: Fortress Press, 1999. 
HINTZ, Kristina; BORGES, Doriam; COUTINHO, Aline; ANDRIES, Thiago Cury. The rise of Brazil's neo-Pentecostal narco-militia. openDemocracy, United Kingdom, 6 May 2021. Disponível em: https://www.opendemocracy. net/en/democraciaabierta/rise-narco-militia-pentecostal-brazil-en/. Acesso em: 17 maio 2021.

JOHNSON, Paul Christopher. Law, Religion, and "Public Health" in the Republic of Brazil. Law \& Social Inquiry, v. 26, n. 1, p. 9-33, 2001.

MACHADO, Lia Zanotta. From the time of rights to the time of intolerance. The neoconservative movement and the impact of the Bolsonaro government: Challenges for Brazilian anthropology. Vibrant Virtual Brazilian Anthropology, v. 17, p. 1-35, 2020.

MACHADO, Marta Rodrigues de Assis; LIMA, Márcia; NERIS, Natália. Racismo e insulto racial na sociedade Brasileira: Dinâmicas de reconhecimento e invisibilização a partir do direito. Novos Estudos CEBRAP, v. 35, n. 3, p. 11-28, 2016.

MAGGIE, Yvonne Alves Velho. Medo do feitiço: relaçôes entre magia e poder no Brasil. Rio de Janeiro: Arquivo Nacional, Órgão do Ministério da Justiça, 1992.

MARIANO, Ricardo. Laicidade à brasileira: católicos, pentecostais e laicos em disputa na esfera pública. Civitas - Revista de Ciências Sociais, v. 11, n. 2, p. 238-258, 16 set. 2011.

MARIANO, Ricardo; ORO, Ari P. The Reciprocal Instrumentalization of Religion And Politics In Brazil. Annual Review of the Sociology of Religion, v. 2, p. 245-266, 2011.

MIRANDA, Ana Paula M. de. Entre o privado e o público: consideraçóes sobre a (in)criminaçáo da intolerância religiosa. Anuário Antropológico, n. 2, p. 125-152, 2010. 
MIRANDA, Ana Paula Mendes. de; CÔRREA, Roberta de Mello; ALMEIDA, Rosiane Rodrigues. de. O "renascimento" da intolerância religiosa e as formas de administração institucional de conflitos no Brasil. In: PERLINGEIRO, Ricardo (ed.). Liberdade Religiosa e direitos humanos. Núcleo de Pesquisa e Extensáo Sobre Ciências do Poder Judiciário (Nupej), TRF-2, 2019. p. 111-146. MIRANDA, Ana Paula Mendes de. A "política dos terreiros" contra o racismo religioso e as políticas "cristofascistas". Debates do NER, Porto Alegre, ano 21, n. 40, 2021.

MONTERO, Paula. Secularização e espaço público: a reinvenção do pluralismo religioso no Brasil. Etnográfica Revista do Centro em Rede de Investigação em Antropologia, v. 13, n. 131, p. 7-16, 2009.

MONTERO, Paula. Secularism and religion in the public sphere in contemporary Brazil. In: SCHMIDT, Bettina; ENGLER, Steven (ed.). Brill Handbooks on Contemporary Religion. v. 13. Brill Academic Publishers, 2016. p. 379-394.

OBALERA DE DEUS, Lucas. Por uma perspectiva afroreligiosa: Estratégias de enfrentamento ao racismo religioso. Rio de Janeiro: Caderno Religião e Política, 2019.

SCOLA, Jorge. Os sentidos da problematizaçáo da prática sacrifical afro-religiosa desde a controvérsia legislativa no Rio Grande do Sul. In: HEIM, Bruno Barbosa; ARAÚJO, Maurício Azevedo de; HOSHINO, Thiago de Azevedo Pinheiro. Direitos dos Povos de Terreiro. Salvador: EDUNEB, 2018.

SÖLLE, Dorothee. Beyond Mere Obedience: Reflections on a Christian Ethic for the Future. [s.1.]: Augsburg Publishing House, 1970.

SULLIVAN, Winnifred Fallers. The Impossibility of Religious Freedom. Princeton and Oxford: Princeton University Press, 2005.

Recebido em: 15/07/2021

Aprovado em: 15/07/2021 